\title{
The Functions of Discourse Markers in Fairy Tale of Thumbelina by Hans Christian Andersen
}

\author{
Herman $^{1}$, Juliana Sihombing ${ }^{2}$, Nguyen Van Thao ${ }^{2}$ \\ ${ }^{1,2}$ English Education Department, Universitas HKBP Nommensen, Medan, Indonesia \\ ${ }^{3}$ Faculty of Philology, Hanoi Pedagogical University 2, Vietnam \\ 1herman@uhn.ac.id, ${ }^{2}$ juliana@uhn.ac.id, ${ }^{3}$ nguyenvanthao@hpuz.edu.vn
}

\begin{abstract}
\section{Keywords:}

Discourse Marker, Interpersonal Function, discourse Analysis, Fairytale.

The aim of this research is to investigate the use of discourse markers in written fairy tale. In order to achieve the aim of this research, the following objective is set to analyze the percentage and the functions of discourse markers in the fairy tale of Thumbelina. The approach to this research is qualitative as well as discourse analysis method was chosen for the analysis. After analyzing the data, the research found that total word count of the fairy tale of Thumbelina was 4,335, which was taken as the basis for calculating the frequency of each DM. Within 4,335 words 41 different DMs were identified, but the number of occurrences of each DM was quite different. Total number of all DMs occurrences was 415 which composed $10.44 \%$ of the total word count. Taking into consideration functions of DMs, there were found 358 occurrences of DMs fulfilling textual functions and 57 occurrences of DMs in interpersonal functions. Based on the result, the percentage of occurrences of discourse markers are more frequent in the textual discourse markers $(86,3 \%)$ than interpersonal discourse markers $(13,7 \%)$.
\end{abstract}

Article History:

Received: 29-06-2018

Revised : 20-08-2018

Accepted: 28-08-2018

Online : 30-08-2018

\author{
This is an open access article under the CC-BY-SA license \\ Crossref \\ https://doi.org/10.31764/ijeca.v1i2.2134
}

\section{A. INTRODUCTION}

Discourse markers play an important role in achieving the communicative goals of socially situated language both in written and spoken discourse. Kohlani (Al Kohlani, 2010) states discourse markers function across sentences boundaries to connect textual units above the sentence and guide the text-receivers' interpretation of text according to the text-producers' communicative intentions. Despite their considerable role in producing texts, discourse markers are thought to be semantically empty and grammatically optional. However, rather than seeing them as meaningless and merely stylistic, Brinton claims that discourse markers fulfill a variety of pragmatic functions on the textual and interpersonal level of discourse (Nevalainen, 1998). Discourse markers, which signal various kinds of boundaries, and assist in turn-taking in spoken discourse or marking of episode in written discourse, are claimed to fulfill textual functions. Discourse markers with interpersonal functions express speaker or writer's attitude, and keep intimacy between the participants. Indeed, discourse markers are communicative tools which organize and evaluate the ideas in the discourse. Thus, the use of these linguistic elements is tied to the communicative purpose of the text. The various linguistic devices that create a text should 
be coherence (the way a sentence makes sense), and cohesive marker (which create link across the boundaries of sentence and also chain related item together).

This research deals with the functions of discourse markers in written language. Discourse markers are the subject of such investigation because they find their use in every genre and may serve as indicators of genre differences. Their frequency in the text and their functions can be influenced by the genre. The researcher is interested to investigate the functions of discourse markers in written story about the 1835 literary fairy tale by Hans Christian Andersen. The researcher chooses Thumbelina because she likes to read and watch about fairy tale especially Andersen's fairy tales. There are some of famous fairy tales by Andersen which known such as the Angle, the Fir Tree, Little Tiny or Thumbelina the Princess and the Pea, the Little Mermaid, the Ugly Duckling, the Red Shoes, the Snow Queen and etc. Undeniably, Andersen's fairy tales do contain universal moral. So, it is not surprising that his works were then translated no less into 147 languages in the world. It is why the researcher takes one. That is the fairy tale of Little Tiny or Thumbelina which much known. According to Wikipedia, Thumbelina is a literary fairy tale written by Danish author Hans Christian Andersen first published by C. A. Reitzel on 16 December 1835 in Copenhagen, Denmark, with "The Naughty Boy" and "The Traveling Companion" in the second installment of Fairy Tales Told for Children. Thumbelina is about a tiny girl and her adventures with appearance and marriage-minded toads, moles, and cockchafers. She successfully avoids their intentions before falling in love with a flower-fairy prince just her size.This tale has been adapted to various media including television drama and animated film. So, researcher is interested to analyze this fairy tale. This research focuses on the functions of discourse markers which developed by Swales (Swales, 1990) and Bhatia (Huckin \& Bhatia, 1995). Therefore, the researchers conduct a research entitled Functions of Discourse Markers in Fairy Tale of Thumbelina by Hans Christian Andersen.

\section{B. METHODS}

The method used in this research is descriptive qualitative research, which means that once the data is considered representative obtained based on what the state of nature in accordance with the data (Sugiyono, 2017). The data obtained through reading, collecting, classifying, analyzing, and then drawing conclusion. A further explanation about qualitative research is also given by Cresswell (Creswell, 2007). Qualitative research is an inquiry process of understanding based on distinct methodological traditions of inquiry that explore a social or human problem, analyzes words, reports detailed views of informants, and conducts the study in a natural setting. The qualitative analysis of the research is based on DM studies of Brinton (Nevalainen, 1998), Aijmer (Aijmer, 2002), Castro (Castro et al., 2010), Hyland (K. Hyland, 2013). DMs were analyzed for both textual and interpersonal functions.

In counting the percentage of DMs, Bungin's formula (Bungin, 2011) is used to find the percentage of DMs that occur in the fairy tale of Thumbelina. The following formula is:

$$
n=\frac{F_{x}}{N} \times 100 \%
$$

Where:

$$
\begin{aligned}
& n=\text { percentage of DMs } \\
& F x=\text { the number of DMs in the fairy tale of Thumbelina } \\
& N=\text { total number of all number of all DMs in the fairy tale of Thumbelina }
\end{aligned}
$$




\section{RESULT AND DISCUSSION}

\section{The Textual Functions of DMs in the Fairy Tale of Thumbelina}

There were found 25 different forms of Discourse Markers. However, the number of occurrences of each DM was considerably different. The five most frequent DMs compose $84.36 \%$ of all textual DMs (see Table 1 ).

Table 1. Frequency and distribution of DMs in textual functions in the fairy tale of Thumbelina

\begin{tabular}{|l|c|c|}
\hline \multicolumn{2}{|c|}{ Total DM (in textual functions) count: 358 } \\
\hline Discourse Markers & Occurrence & Distribution \% \\
\hline And & 192 & 53,63 \\
\hline But & 35 & 9,77 \\
\hline So & 35 & 9,77 \\
Then & 27 & 7,01 \\
\hline Like & 15 & 4,18 \\
\hline Now & 10 & 2,79 \\
As & 7 & 1,95 \\
Or & 6 & 1,67 \\
While, so that & $5(* 2)$ & $1,39(=2.78)$ \\
Because & 4 & 1.11 \\
Just & 3 & 0.83 \\
Nor & 2 & 0,55 \\
\hline At last, indeed, to be & $1(* 12)$ & $0,27(=3.24)$ \\
ready, also, however, & & \\
meanwhile, although, a & & 100 \\
short time before, after & & \\
the time, even, & & \\
immediately, suddenly & 358 & \\
\hline 25 & & \\
\hline
\end{tabular}

Table 1 displays the occurrences of each DM and their percentile representation within the total DM count in the textual functions. DMs which have the same number of occurrence in the corpus are displayed together: their number of occurrences and percentages are demonstrated as per each DM. Table 1 presents that the most frequent DM is and, occurring 192 times and having 53.63\% within the total number of occurrences of DMs. Among other frequent DMs we have but and so (35 occurrences with $9.77 \%$ each), then (27 occurrences with $7.01 \%$ ) and like (15 occurrences with 4.18\%). Furthermore, as, or, while, so that, compose a visible part of DM representation within the corpus. It can be seen the tendency to use such DMs as because and justin the editorials. The discourse markers occur only twice (nor) or once (at last, indeed, to be ready, also, however).

As it was mentioned above, and is the most frequent DM in the fairy tale of Thumbelina. This marker, often called an additive marker or elaborative marker, signal that the utterance following constitutes additional information to the preceding discourse. Simultaneously, and is used to indicate the writer's continuation. For example:

1. "Oh, that can be easily managed," said the fairy. "Here is a barleycorn of a different kind to those which grow in the farmer's fields, and which the chickens eat; put it into a flower-pot, and see what will happen."

2. In the swampy margin of a broad stream in the garden lived the toad, with her son. He was uglier even than his mother, and whenhe saw the pretty little maiden in her elegant bed, he could only cry, "Croak, croak, croak." 
But and so is the second most frequently used discourse marker in the fairy tale of Thumbelina. The function of DM but in these articles is to signal contrastive relationships between discourse stretches. In other words, but fulfills a function of contrastive marker, indicating that the given utterance is either a denial or a contrast of some propositions from the preceding discourse. The DM so, often called as a causative or an inferential marker, signals that the given utterance is a conclusion which follows from the previous discourse. To put it differently, so is a transition which marks consequential steps in the discourse. For example:

a. There was once a woman who wished very much to have a little child, but she could not obtain her wish. At last she went to a fairy, and said, "I should so very much like to have a little child; can you tell me where I can find one?"

b. "Croak, croak, croak," was all her son could say for himself; so the toad took up the elegant little bed, and swam away with it, leaving Tiny all alone on the green leaf, where she sat andwept.

Then is the fourth most frequently used discourse marker in $\mathrm{T}$ the fairy tale of Thumbelina. The DM then, often to refer to discourse acts, sequences, or text stages (frame markers). For example:

a. "Don't speak so loud, or she will wake," said the toad, "and then she might run away, for she is as light as swan's down.

b. We will place her on one of the water-lily leaves out in the stream; it will be like an island to her, she is so light and small, and then she cannot escape; and, whileshe is away, we will make haste and prepare the state-room under the marsh, in which you are to live when you are married."

The fifth most frequently used in the fairy tale of Thumbelina. DM is like marks to help readers grasp functions of ideational material (code glosses). For example:

After a time, all the cockchafers turned up their feelers, and said, "She has only two legs! How ugly that looks." "She has no feelers," said another. "Her waist is quite slim. Pooh! She is like a human being."

As the analysis reveals, the textual DMs in the fairy tale of Thumbelina can be subdivided into three subcategories: transitions, frame markers, and code glosses. Among the most frequent DMs, the transitions, which signal additive and contrastive relationships, are prevailing. Beside this, the consequential transitions are quite common in the fairy tale of Thumbelina, too. A visible part of DMs in the fairy tale compose frame markers which signal text boundaries including such functions of DMs as to sequence, to label text stages and to indicate topic shifts; and code glosses, which signal the restatement of ideational information in other ways. All DMs, mentioned above, represent the textual macro-function, which help to guide readers through the text. Table 2 provides the categorization of the textual functions in the fairy tale of Thumbelina, the forms of DMs which represent each category, and exemplification of the functions. 
Table 2. Sample instances of DMs textual functions in the fairy tale of Thumbelina

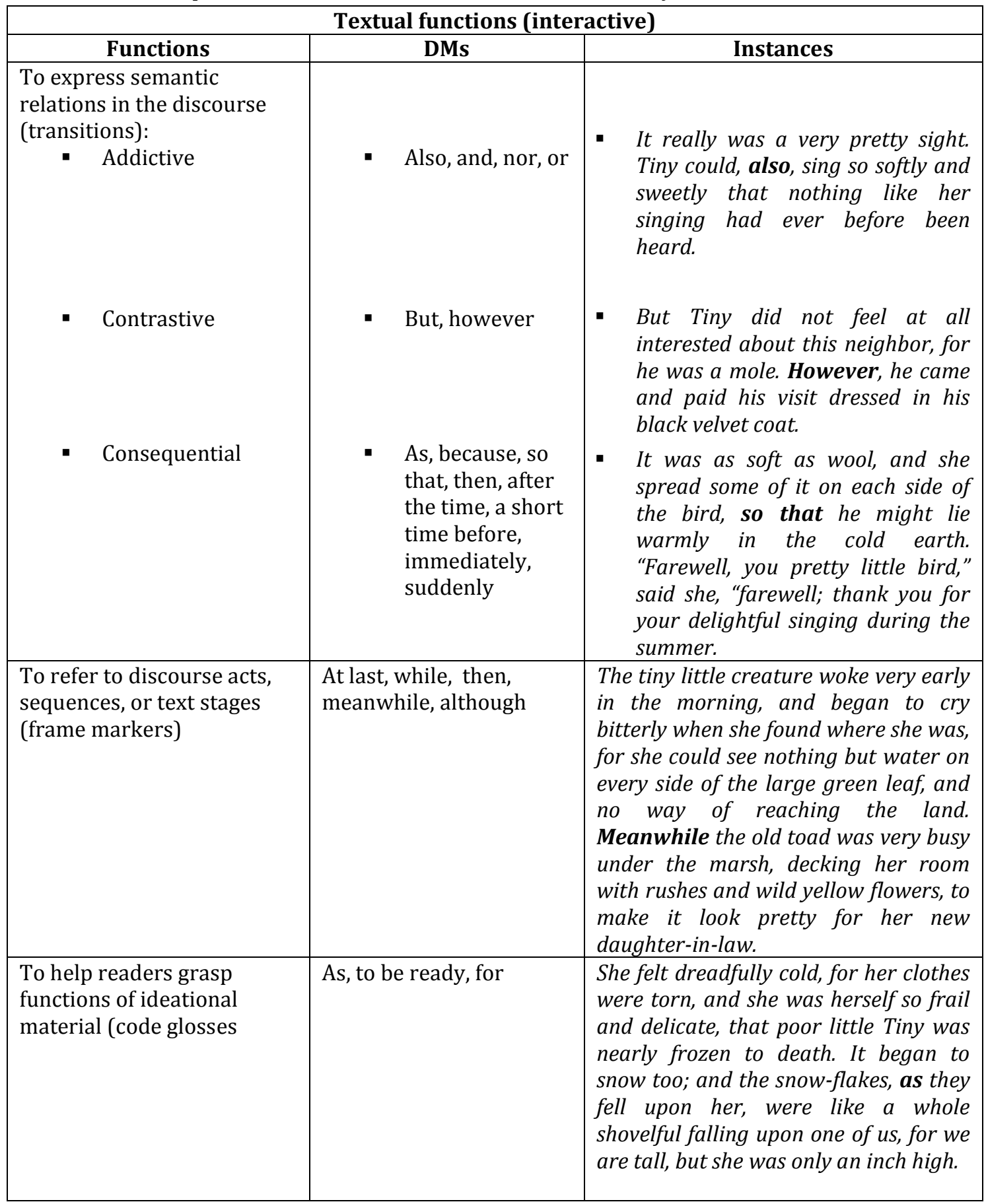

The high use of DMs, representing the textual functions, is clearly an important feature of the fairy tale. However, the interpersonal DMs compose an important part, too, due to the fact that they involve readers in the argument.

\section{The Interpersonal Functions of DMs in the Fairy Tale of Thumbelina}

There were found 57 occurrences of DMs. Among the all occurrences there were found 16 different forms of DMs (see Table 3). 
Table 3. Frequency and distribution of DMs in interpersonal functions in the fairy tale of Thumbelina.

\begin{tabular}{|l|c|c|}
\hline \multicolumn{2}{|c|}{ Total DM (in interpersonal functions) count: 57} \\
\hline DM & Occurrence & Distribution (\%) \\
\hline Said & 30 & 52,63 \\
\hline Might, oh & 6 & 10,52 \\
\hline Yes, really & 5 & 8,77 \\
\hline No & 4 & 7,01 \\
\hline $\begin{array}{l}\text { May, perhaps, possibly, } \\
\text { certainly, especially, } \\
\text { indeed, replied, } \\
\text { nonsense, pooh }\end{array}$ & 3 & 5,26 \\
\hline 16 & $1(* 9)$ & $1,75(=15,75)$ \\
\hline
\end{tabular}

As Table 3 shows the most frequent DM is said (30occurrences with 52,63.\% distribution), next is might and oh (6 occurrences with 10,52\% each) and then asked (5 occurrences with 8.77\%). Some DMs occur four times (yes, really), the others only once (may, perhaps, possibly, certainly, especially, indeed, replied, nonsense, pooh.) The three most frequent DMs said,might and oh, and asked imply writer's certainty to present information and emphasize the force of propositions. For example:

a. The little fishes, who swam about in the water beneath, had seen the toad, and heard what she said, so they lifted their heads above the water to look at the little maiden.

b. "Oh! She is ugly," said all the lady cockchafers, although Tiny was very pretty. Then the cockchafer who had run away with her, believed all the others when they said she was ugly, and would have nothing more to say to her, and told her she might go where she liked.

c. He took the gold crown from his head, and placed it on hers, and asked her name, and if she would be his wife, and queen over all the flowers.

With reference to the research results, the interpersonal functions of DMs in the fairy tale of Thumbelina can be subdivided into four sub-functions. Table 4 provides the categorization of interpersonal functions in the editorials, the forms of DMs which represent each category and exemplification of the functions.

Table 4. Sample instances of DMs interpersonal functions in the fairy tale of Thumbelina

\begin{tabular}{|l|l|l|}
\hline \multicolumn{2}{|c|}{ Interpersonal functions (interactional) } \\
\hline \multicolumn{1}{|c|}{ Functions } & \multicolumn{1}{c|}{ DMs } & \multicolumn{1}{c|}{ Instances } \\
\hline $\begin{array}{l}\text { To emphasize writer's } \\
\text { (bortainty in proposition }\end{array}$ & Indeed, especially, yes, no, & $\begin{array}{l}\text { Oh, how frightened little Tiny } \\
\text { felt when the cockchafer flew } \\
\text { with her to the tree! But } \\
\text { especially was she sorry for the } \\
\text { beautiful white butterfly which } \\
\text { she had fastened to the leaf, for } \\
\text { if he could not free himself he } \\
\text { would die of hunger. }\end{array}$ \\
\hline To express writer's & Really, pooh & "You poor little creature," said \\
\hline
\end{tabular}




\begin{tabular}{|l|l|l|}
\hline $\begin{array}{l}\text { attitude to proposition } \\
\text { (attitude markers }\end{array}$ & $\begin{array}{l}\text { the field-mouse, who was really } \\
\text { a good old field-mouse, "come } \\
\text { into my warm room and dine } \\
\text { with me." }\end{array}$ \\
\hline $\begin{array}{l}\text { To build relationship } \\
\text { with readers } \\
\text { (engagement markers) }\end{array}$ & Said, asked, replied & $\begin{array}{l}\text { "Nonsense, replied the field- } \\
\text { mouse. "Now don't be obstinate, } \\
\text { or I shall bite you with my white } \\
\text { teeth. }\end{array}$ \\
\hline $\begin{array}{l}\text { To express writer's } \\
\text { reluctance to } \\
\text { information (hedges) }\end{array}$ & $\begin{array}{l}\text { Nonsense, perhaps, possibly, } \\
\text { might, may }\end{array}$ & $\begin{array}{l}\text { Perhaps this was the one who } \\
\text { summer, she said; "and how } \\
\text { much pleasure it gave me, you } \\
\text { dear, pretty bird." }\end{array}$ \\
\hline
\end{tabular}

As it can be seen from Table 4, among the DMs which represent the interpersonal functions there are boosters which indicate the writer's confidence in a particular position, attitude markers, engagement markers, and hedges which withhold writer's full commitment to a proposition.

Based on the analysis above, the percentage of each functions of DMs as follows:

Total words count of the fairy tale of Thumbelina $\quad=4,335$

Within 4,335 words 41 different DMs

Total number of textual function occurrences $\quad=358$

Total number of interpersonal function occurrences $=57$

Total number of all DMs occurrences $\quad=415$

The percentage of all DMs occurrences $=\quad$ all DMs occurrences

Total words count of the fairy tale of Thumbelina

$=415 \times 100 \%$

The percentage of all DMs occurrences $=10,44 \%$

The percentage of textual DMs $=\quad$ textual DMs occurrences

$$
\begin{aligned}
& \text { Total number of all DMs occurrences } \\
& =\frac{358 \times 100 \%}{415}
\end{aligned}
$$

The percentage of textual DMs $=86,3 \%$

The percentage of textual DMs = interpersonal DMs occurrences

$$
\begin{aligned}
& \text { Total number of all DMs occurrences } \\
= & \frac{57 \times 100 \%}{415}
\end{aligned}
$$

The percentage of textual DMs $=13,7 \%$

\section{CONCLUSION AND SUGGESTIONS}

Based on the finding in the analysis, the conclusion of the research is the DMs in the fairy tale of Thumbelina fulfill a number of textual and interpersonal functions which contribute to the management of the discourse and engagement of the readers by noticing and evaluating the text material. Taking into consideration the use of DMs in this genre, the most frequent of them fulfill 
textual functions. However, the interpersonal functions are of the considerable importance owing to their influence on the readers.

Total word count of the fairy tale of Thumbelina was 4,335, which was taken as the basis for calculating the frequency of each DM. Within 4,335 words 41 different DMs were identified, but the number of occurrences of each DM was quite different. Total number of all DMs occurrences was 415 which composed $10.44 \%$ of the total word count. Taking into consideration functions of DMs, there were found 358 occurrences of DMs fulfilling textual functions and 57 occurrences of DMs in interpersonal functions.

As it can be seen from data analysis, DMs in textual functions compose $86,3 \%$ of the total DMs count, whereas DMs in interpersonal functions compose only $13,7 \%$. The textual functions of DMs in the fairy tale of Thumbelina are apparently dominant over the interpersonal.

\section{REFERENCES}

Aijmer, K. (2002). The topic-changer Now. In English Discourse Particles: Evidence from a Corpus (pp. 5796). http://books.google.com/books?id=_QF_6DWa0FoC\&pgis=1

Al Kohlani, F. A. (2010). The function of discourse markers in Arabic newspaper opinion articles. ProQuest Dissertations and Theses, 516. http://proxy.libraries.smu.edu/login?url=https://search.proquest.com/docview/250848997?accou ntid=6667\%0Ahttps://smu.primo.exlibrisgroup.com/discovery/openurl?institution=01SMU_INST\& vid=01SMU_INST:01SMU\&?url_ver=Z39.88-2004\&rft_val_fmt=info:ofi/fmt:kev:mtx

Bungin, B. (2011). Penelitian Kualitatif: Komunikasi, Ekonomi, Kebijakan Publik, Dan Ilmu Sosial Lainnya. In Kencana. https://doi.org/10.1002/jcc.21776

Castro, L., Baião, F., \& Guizzardi, G. (2010). A linguistic approach to conceptual modeling with semantic types and OntoUML. Proceedings - IEEE International Enterprise Distributed Object Computing Workshop, EDOC, 215-224. https://doi.org/10.1109/EDOCW.2010.56

Creswell, J. W. (2007). Qualitative inquiry and research designs: Choosing harmony among five traditions. In The Journal of Pediatrics. https://doi.org/10.1016/S0022-3476(89)80781-4

Huckin, T. N., \& Bhatia, V. K. (1995). Analysing Genre: Language Use in Professional Settings. The Modern Language Journal, 79(2), 265. https://doi.org/10.2307/329626

K. Hyland. (2013). Discourse Studies Reader: Essential excerpts. Bloomsbury. https://doi.org/10.5040/9781472541925

Nevalainen, T. (1998). L. Brinton, Pragmatic markers in English: grammaticalization and discourse functions. Topics in English Linguistics 19. Berlin and New York: Mouton de Gruyter, 1996. Pp. xvi + 412. Cloth DM 168, ISBN 311014872 2. English Language and Linguistics, 2(1), 150-154. https://doi.org/10.1017/s1360674300000770

Sugiyono. (2017). Sugiyono, Metode Penelitian. Penelitian, 34-45. https://doi.org/10.1021/ol7029646

Swales, J. (1990). Genre Analysis: English in Academic and Research Settings (Cambridge Applied Linguistics). In Journal of Advanced Composition (Vol. 11). 